\title{
Socially responsible practices and workplace harassment, in a municipality as a political administrative organism
}

\section{Prácticas socialmente responsables y acoso laboral, en un municipio como organismo político administrador}

\author{
PÉREZ-BRAVO, Julia†* \\ Universidad Autónoma de Querétaro, Cerro de las Campanas S/N, Centro Universitario, Querétaro, Qro. C.P. 76010. \\ ID $1^{\text {st }}$ Author: Julia, Pérez-Bravo / ORC ID: 0000-0002-1310-0145, Researcher ID Thomson: N-3319-2018, CVU \\ CONACYT ID: 501992
}

\begin{abstract}
Corporative social responsability, in recommendations or international guidelines, sets forth in the section of labor standards respect and care for the integrity of workers as an interested party within an organization. Workplace harassment in organizations harms workers morally, psychologically and physically.It is undeniable that in plenty of organizations workers are either misstread or harassed when they are either no longer requiered in said organization or are new entrants or there is some rivalry in between. Due to the aforementioned, it was pertinent to investigate the existence of these variables in the government of the Municipality of San Juan del Río, Querétaro, as an administrative political body, in the 20152018 administration, with the aim of knowing the practices in labor matters wich uses dependency, as a socially responsible body. The problem was analyzed through a quantitative approach with descriptive scope using the types of documentary and field research, using the case study of the Municipal Culture and Tourism Directorate, with the hypothetical deductive method and nor experimental design. The results derived from the research instruments show that the agency has good labor practices in a percentage of $40 \%$, in the same way, they show that the existence of workplace harassment or abuse is low, since $25 \%$ of the dependency workers were surveyed and harassment practices were found in $16.66 \%$.
\end{abstract}

Corporative social responsibility, Workplace harassment, San Juan del Río, Qro

\begin{abstract}
Resumen
La responsabilidad social corporativa, en las recomendaciones o directrices internacionales, plantean en el apartado de estándares laborales el respeto y cuidado de la integridad de los trabajadores como parte interesada en el ámbito interno de una organización. El acoso laboral en las organizaciones daña a los trabajadores moral, psicológica o físicamente. Es innegable que en diversas organizaciones se maltrata o se acosa a los trabajadores cuando no se le quiere más en la misma, cuando es de nuevo ingreso, o por cualquier rivalidad. Por lo anterior mencionado resultó pertinente investigar sobre la existencia de esas variables en el gobierno del Municipio de San Juan del Río, Querétaro, como organismo político administrador, en la administración 2015-2018, con el objetivo de conocer las prácticas en materia laboral que utiliza la dependencia, como un organismo socialmente responsable. Se analizó el problema mediante un enfoque cuantitativo con alcance descriptivo utilizando los tipos de investigación documental y de campo, usando el estudio del caso de la Dirección de Cultura y Turismo Municipal, con el método hipotético deductivo y diseño no experimenta. Los resultados derivados de los instrumentos de investigación dan muestra de que la dependencia tiene buenas prácticas laborales en un porcentaje del $40 \%$, de igual forma, muestran que la existencia del acoso o maltrato laboral es baja, toda vez que se encuestó al $25 \%$ de los trabajadores de la dependencia y se encontraron prácticas de acoso en un $16.66 \%$.
\end{abstract}

Responsabilidad social corporativa, Acoso laboral, San Juan del Río, Querétaro

Citation: PÉREZ-BRAVO, Julia. Socially responsible practices and workplace harassment, in a municipality as a political administrative organism. Journal-Labor and Demographic economic. 2020. 4-7:14-26.

$\dagger$ Researcher contributing first author. 


\section{Introduction}

This research topic refers to corporate social responsibility (CSR) applied in a public institution, which, when referring to the public sector, is designated governmental social responsibility (RSG).

In view of the fact that CSR is a very broad topic, an example of which is the content of one of the most relevant documents on the matter, the Global compact, which in its content includes 4 thematic areas and 10 principles, in This work only includes what is related to labor standards. This is an interesting topic to address in this research since it is just beginning to permeate the interest of politicians in Mexico, although in other areas, such as accountability or transparency, not in the area of labor practices and You can say that there is little research on the matter.

This research also includes the topic of mistreatment or workplace harassment in the same public organization, which is intertwined with the labor standards of corporate social responsibility, by virtue of the fact that the organization that allows harassment or mistreatment in the workplace in its practices, it cannot be said that it is a socially responsible company.

In order to limit the investigation, it only refers to the governmental social responsibility in the labor area of a dependency of the Municipality of San Juan del Río, Querétaro, the Directorate of Culture and Tourism, where the prevalence or not of abuse will be verified. or workplace harassment in their human capital.

This situation of mistreatment or workplace harassment is observed in organizations, both private and public, facts of which there is already documented evidence through scientific research in various parts of the world, although in Mexico, the relative research The topic in the public sector is at an incipient stage and almost nil if it is intertwined with corporate social responsibility where the main interest is that all its practices are carried out with the interested parties in an ethical framework, making the leaders of that they can serve, produce and generate benefits and profits, but aware that their actions have a positive or negative effect on their internal and external environments.
It is worth mentioning in this work how worrisome the practices of mistreatment or workplace harassment are, since it can cause damage to human capital, which ranges from the moral, the psychological and even the physical, as can be seen in the existing literature; This can also cause damage to organizations, such as costs due to absenteeism, discomfort at work or illnesses caused by the same labor abuse, a situation that, on occasions, is not perceived by the leaders.

With this research, we sought to know the practices in labor matters used by the Directorate of Culture and Tourism of San Juan del Río, Qro., Administration 2015-2018, as a socially responsible body, particularly those practices that it carries out to avoid abuse, harassment, workplace violence or mobbing.

The research methodology consisted of analyzing the problem through a quantitative approach with a descriptive scope using the types of documentary and field research, using the case study of the Municipal Culture and Tourism Directorate, with the hypothetical deductive method and non-experimental design. The results derived from the research instruments show that the agency has good labor practices in a percentage of $40 \%$, in the same way, they show that the existence of harassment or labor abuse is low, since $25 \%$ of dependency workers and harassment practices were found in $16.66 \%$.

\section{Theoretical framing}

\section{Corporate social responsibility, general outline for management in the public sector}

Based on the definitions proposed by various authors on the matter, it can be affirmed that corporate social responsibility is the set of obligations, legal and ethical commitments, national and international, towards the interest groups with which an organization is committed on a voluntary basis, taking into account its economic objectives and its own interests, making them compatible with the social, labor, economic and environmental impacts of the practices of the same organization. 
This topic has aroused the interest of scholars dedicated to social areas and those of other areas, who have identified the magnitude of the importance of performing socially responsible in their work environment, thus it is observed that there is social responsibility in corporations, technologies, engineering, medicine, law, in short, in the exercise of each and every one of the professions.

From a global perspective, and thanks to information technologies, today it is possible to enter vast data generated over time on social responsibility, from different perspectives, different authors and different geographical points on our planet, on corporate social responsibility.

Today it can be learned from the background of Corporate Social Responsibility (CSR) framed in the vision of various authors such as De la Cuesta (2005), who contextualized it in the 1920s as a corporate action of a company, not as a philanthropic action of a single entrepreneur. Various authors affirm that CSR emerged in the 1950s, linking it with the rapid growth of American companies and the importance they take on for society. Others, such as Gilli (2012), take it to 1960, when the question is posed in current terms and the company is required to assume responsibility for social problems and to contribute to their solution. Despite the above, there are those who go further back like Peraza (2014), who from an epistemological point of view places CSR in the Middle Ages, since it was born when rules of conduct, urban planning and ethical values were established. and morals for the coexistence of man in society or community.

In the same way, it is possible to give an account of international organizations and their documents, which have participated at various times and have laid the main foundations in matters of social responsibility. Over time, these have provided extensive reference material to know and implement CSR actions in any organization, so they have, to name a few:
- The Organization for Economic Cooperation and Development (OECD), which in 1976 prepared the first version of the guidelines for multinational companies, which were revised again in the years 2000 and 2011, adding the dimension of sustainable consumption as a new responsibility.

The International Labor Organization (ILO), which approved in 1977 the Tripartite Declaration of Principles on Multinational Enterprises and Social Policy, covering the issues of working and living conditions, labor relations, employment and training.

The Caux Round Table, founded in 1986, which focuses its interest on constructive economic and social relations between member countries and their responsibilities.

- The creation in 1997 of the Global Reporting Initiative (GRI), where the Guide for preparing a corporate sustainability report is developed.

The Lisbon Summit, in March 2000, which addresses, among other issues, social issues in favor of people in situations of poverty and social exclusion.

- The publication of the Green Book on corporate social responsibility of the European Community in 2001, which establishes ethical, social and environmental guidelines for companies.

- $\quad$ The preparation and signing of the Global Compact, at the initiative of the United Nations (UN), thereby creating the framework that allows the management of CSR in companies in a global environment and under universal ethical values. This began at the World Economic Forum in 1999, taking definitive form in 2000 and updated in 2004, where the fight against corruption embodied in the tenth principle was added as a pillar of defense.

The International Organization for Standardization (ISO) which, in 2005, implemented the global standardization project ISO 26000 in the field of social responsibility. 
The previous organizations and the collection generated induce to know the basic guiding principles in the form of norms, guides, recommendations or guidelines, which coincide in that the main aspects or issues to consider, when implementing CSR in an organization, are rights human rights, labor standards, the environment, anti-corruption and sustainable consumption.

Mexico is not far behind, beginning the institutionalization and promotion of the social responsibility movement in May 2000 when the Third Congress of Social Responsibility of the Americas was held. Although it can be said that work had already been done on the matter since the creation of the Mexican Center for Philanthropy (CEMEFI) in 1998, which was strengthened with the appearance of the Alliance for Corporate Social Responsibility (AliaRSE) in 2001. These are the promoting and certifying bodies in the country, which have made companies in Mexico interested in the matter and initiate various actions to be socially responsible.

Currently operating in Mexico, in matters of social responsibility, business associations, academic institutions, international organizations, public bodies, civil society and organizations of corporate social responsibility, with various lines of action, such as articulation, advice, training, dissemination, standardization, financing, research and recognition. These may be in one or more of the following domains: consumer and customer, corporate governance, social investment, environment, labor practices, suppliers, and general corporate social responsibility.

The truth is that CSR has managed to permeate around the world, mainly in private companies, whose executives have managed, or are managing, to take advantage of the benefits of being socially responsible in their practices. Mexico, immersed in the world of competitiveness, bound by globality, has not been the exception. Thus, there are already companies working one hundred percent and with national and international distinctions, presenting reports of socially responsible companies or at various levels of the implementation of CSR within the organization.
And, what about public sector institutions and officials in matters of social responsibility? What do public servants do to obtain or regain the trust of society and its stakeholders in general? Being currently one of the greatest challenges to strengthen the confidence of citizens in the public sector, organizations in this sector must also aspire to excellence and work to achieve it. It is through the incorporation of guidelines established in international guidelines or guides to their strategies, operations of the processes of the organizations and agencies, that it will be achieved.

What rules the conduct of public servants in our country regarding the ethical principles that must govern the exercise of the functions they perform in the public administration, especially in local or municipal governments, who are closer to individuals and perceive firsthand demands for a better service and greater transparency in the management of resources in general? It is desirable that public officials, elected or hired to fulfill a function in the municipalities, carry out their work effectively and efficiently, with honesty and transparency, to meet the demand for community services and be accountable for their management, that is, , that they are socially responsible, since they are the obligated and responsible for granting a better quality of life to citizens through the exercise of their functions in a responsible manner. Although what is related to social responsibility is not mandatory, except for what is established in local, national or international laws (such as those related to labor, the environment or human rights), it is a requirement of society in general that act in a socially responsible manner in all public sector practices. What can be done to ensure that SR is managed within the mayors or municipal presidencies? It is known that in various parts of the world social responsibility in the public sector is in an incipient stage, while in others these guidelines are already applied, knowing that they are due to citizens, to whom answers must be given and who must be an example of social responsibility. 
However, the organizations that are working on social responsibility are those that have the experience and maturity to be aware that through the development of active SR policies, defined and aligned with their strategies, they reinforce their contribution to the sustainability of the system and that, in addition, enhance integrity, transparency, social commitment, efficiency and, as a result, the reputation of the agencies or agencies, by extension, of the public sector.

Then, CSR must be redefined for the public sector, making the principles, norms, recommendations, guidelines and guides existing in the international and national context its own, adapting what is necessary, not as far as possible, but in the requirement of what It is impossible to manage it, initially, in the smallest cell of the government sector and why not, starting from the base of the pyramid, to permeate up the rungs with an ethical and socially responsible act in government. The main function of the latter is to serve, in whatever field, the citizens with probity, quality, honesty, and if I may express myself, in a good way, the treatment of which the country suffers. Given that the operating agencies in Mexico can act in articulation, advice, training, dissemination, standardization, financing, research and recognition, a first step is to approach them, in order to receive the necessary guidance to start the management of social responsibility by within the organization and adhere to the requirements established by them. That is to say, that the implementation of socially responsible practices begins, the review of processes to make them more sustainable, that responsible criteria are incorporated into their hiring processes and that they annually prepare sustainability and corporate governance reports to achieve recognition or certification.

Few definitions are found for the term Government Social Responsibility (GSR). One of them is from Oxfam International, an organization that affirms that public or governmental social responsibility is that of the institutions and administrations in charge of designing and executing public policies, whose actions are specified in laws, decrees and regulations that have a great impact on the natural and social environment of its jurisdiction.
This body also affirms that the social responsibility of government entities is not only external, that is, regulating the activities of individuals and organizations, companies, etc., that are under its administrative umbrella; but also internally, in the management of its activities with the personnel who are part of them.

For the Ministry of Public Administration and Management of the Municipality of Córdoba in Argentina, the RSG is the set of comprehensive and interrelated strategic decisions, aimed at promoting the improvement of the quality of life of citizens, the environment, and health and the welfare of State workers, thus contributing to sustainable development. This ministry affirms that assuming the concept of governmental social responsibility as a management model implies guaranteeing transparency in actions, facilitating access to public information, providing quality services to citizens, contributing to the development of human resources and promoting the use and development of cutting-edge technologies.

\section{Work harassment or mobbing}

Violence in the workplace, workplace harassment or mobbing, is any action taken in the workplace that manifests itself against a worker, violence, threat of violence or abuse by colleagues or boss, regardless of the hierarchical level nor if they are directly or indirectly linked. It can be done both inside and outside the workplace and begin with threats or verbal aggression, ending with physical attacks and even homicide.

There are various definitions of mobbing, from recognized authors on the subject, of which some are presented that expand the concept, since characteristics of the phenomenon can be observed. González de Rivera (2002), defined the term mobbing as: The attack of a coalition of weak members of the same species against a stronger individual; or that of the majority of them against a different individual for some difference, defect or significant feature. 
At the beginning of the 1990s, Heinz Leymann, led the study of mobbing towards work psychology, being the first to point out the characteristics and psychological effects of abuse on the victim. Leymann defined mobbing as: Psychological terror in the workplace consists of hostile communication directed by one or more individuals against another, which is thus dragged into a position of robbery that takes place frequently and for a long time.

For Glas (1982), mobbing includes threatening, intimidating, abusive physical or verbal behaviors. For their part, Chappell and Di Martino (1999) divide workplace violence into two main branches: physical and psychological violence, with the first being the use of physical force against another person or group, which causes physical and sexual damage. or psychological and in the second, the deliberate use of power or threats of recourse to physical force against another person or group, which can damage physical, mental, spiritual, moral or social development.

\section{Various behaviors of violence at work}

Various behaviors of violence at work can be identified, as mentioned by Chappell and Di Martino (1999), which are presented as a table to better identify the different aggressions that a person who is a victim of mobbing may suffer.

\begin{tabular}{|l|l|}
\hline \multicolumn{2}{|c|}{ Homicide Violation } \\
\hline Stole & Injuries \\
\hline battered & Physical assaults \\
\hline kicking & Bites \\
\hline Punching & Spit \\
\hline Scratches & Punctures and pinches \\
\hline watch & $\begin{array}{l}\text { Racial and sexual } \\
\text { harassment }\end{array}$ \\
\hline Group bullying & Bullying \\
\hline Intimidation & Threats \\
\hline Isolation & Offensive messages \\
\hline Aggressive postures & $\begin{array}{l}\text { Interference with work, } \\
\text { tools, and equipment }\end{array}$ \\
\hline Hostility & $\begin{array}{l}\text { Foul and obscene } \\
\text { language }\end{array}$ \\
\hline Screams & Nicknames \\
\hline indirect & Deliberate silence \\
\hline
\end{tabular}

Table 1 Violent behavior at work, Chappell and Di Martino (1999)

Source: Own elaboration based on Prado (1999, p. 85)

\section{Research methodology}

\section{The purpose of the investigation}

Considering that the investigation was justified since there are various investigations, in different areas of the Social Sciences, that show the existence of workplace harassment in organizations, mostly in public organizations and that, in Mexico, there is a lack of field work in the issue and that to eradicate workplace harassment in public organizations, serious, ethical and responsible behavior is required on the part of the organization, establishing adequate mechanisms to achieve a work environment free of hostilities.

Likewise, considering that the intention of this investigation was to know the existence of labor abuse or mobbing within the Directorate of Culture and Tourism of San Juan del Río, Qro., Administration 2015-2018 and if actions are taken to prevent the workplace harassment in order to be socially responsible, the following type, method and investigation technique was established:

\section{Type of research carried out}

In this work, the problem was analyzed through a quantitative approach with a descriptive scope, using the types of documentary and field research. The case study of the Municipal Culture and Tourism Directorate of San Juan del Río, Querétaro was used.

\section{Methods used in its realization}

\section{The method used was the hypothetical deductive}

\section{Research design}

The research design was non-experimental with a descriptive cross-sectional design. This is due to the fact that the existing situations were observed, analyzing what was the level, state or presence of the independent variables of the investigation and the relationships between them, which provided a vision of the prevailing situation. 


\section{Research techniques}

The techniques used to obtain information were documentary and field, through observation and questionnaire.

Observation. Non-participatory observation was carried out in this research. When going to the unit under study, the ways in which they developed their daily activities were visualized in the first approaches to the objects of study.

Interview. A questionnaire was used as a research instrument, which was applied to the workers of the dependency under study, at different hierarchical levels, who were the actors who gave answers to the research questions.

\section{Analysis unit}

The unit of analysis was the Municipal Culture and Tourism Directorate of San Juan del Río, Querétaro, with the areas dependent on this direction, which are:

\section{Head of cultural organization}

a) Coordination of cultural organization

b) Coordination of the cultural and convention center

\section{Head of cultural services}

a) Coordination of the house of culture

b) Coordination of artistic initiation

III. Head of cultural heritage

a) Library coordination

b) Coordination of the museum of death

c) Coordination of historical archive

d) Coordination of own cultures

IV. Tourism Headquarters

a) Coordination of links with the tourism sector

\section{Information analysis and crossing of variables}

In order to answer the questions posed to affirm or refute the general hypothesis through the application of the proposed research instruments, analyzes of the data obtained were carried out, with whose information it was possible to carry out the crossovers between independent and dependent variables. and thus reach conclusions, carrying them out in the following way:

\section{Results}

Obtaining results from an investigation instrument consisting of a questionnaire to detect the existence, or not, of workplace harassment or mobbing in work practices in the agency in question.

The LIPT-60 questionnaire is the Spanish version of the LIPT 45 of the Leymann Inventory of Psychological Terrorization, modified by the Madrid Institute of Psychotherapy and Research (1999). The instrument includes 15 new items and provides the possibility of answering the questionnaire by adding degrees of intensity to the behaviors received.

According to González and RodríguezAbuin (2003), there are two Spanish versions of the LIPT, the dichotomous and the scalar; for the purposes of this work, the dichotomous is used. This retains the administration instructions and response methodology of LIPT 45, which consists of verifying whether or not there are workplace harassment practices, asking the subject if a certain situation of harassment has taken place, giving them the only response options Yes or not.

The other Spanish version is of the scalar type, the same in terms of the description of the items, but in which the response possibilities are extended to include a Likert-type assessment of the intensity with which each of the bullying behaviors has affected the subject, from zero to four. 
This includes the assessment of the dimensions of psychological harassment perceived at work and reports on the profile of harassment experienced at work, since this can be experienced predominantly in one or more dimensions, thus defining forms of harassment, which facilitates the understanding of the harassment experienced by the individual and the design and implementation of eradication strategies in the organization.

In both cases, six subscales or large sections of harassment are analyzed that González and Rodríguez-Abuin (2005) call the five main maneuvers to destroy a good professional.

1.- Subscale of labor discredit (DL) $=$ items 5 , $10,17,18,28,49,50,54,55,56,57,58$, 59,60 .

2.- Impairment of progress subscale $(E P)=$ items $14,27,32,33,34,35,37$.

3.- Incommunication or communication blocking subscale $(\mathrm{BC})=$ items $3,11,12$, $13,15,16,51,52,53$.

4.- Covert bullying subscale (IE) $=$ items 7,9 , 43, 44, 46, 47, 48.

5.- Manifest bullying subscale (MI) = items 1,2 , $4,8,19,29$.

6.- Subscale of personal loss of prestige $(\mathrm{PD})=$ items 6, 20, 21, 24, 25, 30, 31.

In the present work, the application of the questionnaire was carried out at random to the dependency workers, to whom they were available and who were interested in collaborating in the assessment of harassment. The questionnaire constructed in a dichotomous manner was used, that is, the subject was asked if a certain bullying strategy had taken place, giving the only answer options Yes or No. This instrument was applied to ten subjects, five men and five women. The mean age of the sample was 48.27 years, with a standard deviation of 18.22. The age range was between a minimum of 40 and a maximum of 77 years.
The total LIPT, defined as the number of positive responses to the questionnaire or the total number of different workplace bullying strategies experienced by the subject was, as a group mean, 1.2 with a standard deviation of 1.41 and a range of 1 to 5 . The frequencies of positive responses to each strategy are presented in Table 5.

When establishing the comparison by sex, marked differences were detected in the total LIPT. The mean in men was 1.6 with a standard deviation of 1.41 , which was double that of women, which was .8 with a standard deviation of 0 .

Regarding the gender of the cases in which workplace harassment was manifested, $33.33 \%$ were women and $66.66 \%$ men.

\begin{tabular}{|c|c|c|}
\hline $\begin{array}{l}\text { Item } \\
\text { No. }\end{array}$ & ITEM & $\begin{array}{l}\text { DICOTOMIC } \\
\text { LIPT = 10, } \\
\text { percentage of } \\
\text { positives }\end{array}$ \\
\hline 1 & $\begin{array}{l}\text { His superiors do not let } \\
\text { him express himself or } \\
\text { say what he has to say. }\end{array}$ & $10 \%$ \\
\hline 2 & $\begin{array}{l}\text { They interrupt him when } \\
\text { he speaks. }\end{array}$ & $10 \%$ \\
\hline 3 & $\begin{array}{l}\text { His classmates make it } \\
\text { difficult for him to } \\
\text { express himself or do not } \\
\text { let him speak. }\end{array}$ & $10 \%$ \\
\hline 4 & $\begin{array}{l}\text { They yell or scold you } \\
\text { loudly. }\end{array}$ & 0 \\
\hline 5 & $\begin{array}{l}\text { They unfairly criticize } \\
\text { their work. }\end{array}$ & $30 \%$ \\
\hline 6 & $\begin{array}{l}\text { They criticize his private } \\
\text { life. }\end{array}$ & 0 \\
\hline 7 & $\begin{array}{l}\text { You receive threatening, } \\
\text { insulting and accusing } \\
\text { phone calls. }\end{array}$ & 0 \\
\hline 8 & $\begin{array}{l}\text { You are threatened } \\
\text { verbally. }\end{array}$ & 0 \\
\hline 9 & $\begin{array}{l}\text { Receive threatening notes } \\
\text { or writings. }\end{array}$ & 0 \\
\hline 10 & $\begin{array}{l}\text { They do not look at you } \\
\text { or look at you with } \\
\text { contempt or with gestures } \\
\text { of rejection. }\end{array}$ & 0 \\
\hline 11 & $\begin{array}{l}\text { They ignore your } \\
\text { presence, they don't } \\
\text { answer your questions. }\end{array}$ & 0 \\
\hline 12 & $\begin{array}{l}\text { People have stopped or } \\
\text { are not talking to you. }\end{array}$ & $10 \%$ \\
\hline 13 & $\begin{array}{l}\text { He can't talk to anyone, } \\
\text { they avoid him. }\end{array}$ & 0 \\
\hline 14 & $\begin{array}{l}\text { You are assigned } \\
\text { (without justification) a } \\
\text { workplace that keeps you } \\
\text { isolated from the rest of } \\
\text { your colleagues. }\end{array}$ & 0 \\
\hline
\end{tabular}

PÉREZ-BRAVO, Julia. Socially responsible practices and workplace harassment, in a municipality as a political administrative organism. Journal-Labor and Demographic economic. 2020 


\begin{tabular}{|c|c|c|}
\hline 15 & $\begin{array}{l}\text { They prohibit your } \\
\text { colleagues from talking } \\
\text { to you. }\end{array}$ & 0 \\
\hline 16 & $\begin{array}{l}\text { They are generally } \\
\text { ignored or treated as if } \\
\text { they were invisible. }\end{array}$ & 0 \\
\hline 17 & $\begin{array}{l}\text { They slander you and } \\
\text { whisper behind your } \\
\text { back. }\end{array}$ & 0 \\
\hline 18 & $\begin{array}{l}\text { They spread false or } \\
\text { unfounded rumors about } \\
\text { you. }\end{array}$ & $10 \%$ \\
\hline 19 & $\begin{array}{l}\text { They make a fool of you, } \\
\text { they make fun of you. }\end{array}$ & 0 \\
\hline 20 & $\begin{array}{l}\text { They treat him as if he } \\
\text { were mentally ill or make } \\
\text { him understand. }\end{array}$ & 0 \\
\hline 21 & $\begin{array}{l}\text { They try to force him to } \\
\text { have a psychiatric exam } \\
\text { or psychological } \\
\text { evaluation. }\end{array}$ & 0 \\
\hline 22 & $\begin{array}{l}\text { They make fun of any } \\
\text { deformity or physical } \\
\text { defect you may have. }\end{array}$ & 0 \\
\hline 23 & $\begin{array}{l}\text { They imitate his gait, his } \\
\text { voice or his gestures to } \\
\text { make a fool of him. }\end{array}$ & 0 \\
\hline 24 & $\begin{array}{l}\text { They attack or make fun } \\
\text { of your political } \\
\text { convictions or your } \\
\text { religious beliefs. }\end{array}$ & 0 \\
\hline 25 & $\begin{array}{l}\text { They ridicule or make } \\
\text { fun of your private life. }\end{array}$ & 0 \\
\hline 26 & $\begin{array}{l}\text { They make fun of their } \\
\text { nationality, origin or } \\
\text { place of origin. }\end{array}$ & 0 \\
\hline 27 & $\begin{array}{l}\text { You are assigned a } \\
\text { humiliating job. }\end{array}$ & 0 \\
\hline 28 & $\begin{array}{l}\text { Their work is evaluated } \\
\text { in an unfair and } \\
\text { malicious manner. }\end{array}$ & 0 \\
\hline 29 & $\begin{array}{l}\text { Her decisions are always } \\
\text { questioned or hampered. }\end{array}$ & 0 \\
\hline 30 & $\begin{array}{l}\text { They make insults or } \\
\text { comments at you in } \\
\text { obscene or degrading } \\
\text { terms. }\end{array}$ & 0 \\
\hline 31 & $\begin{array}{l}\text { Sexual advances or } \\
\text { gestures are made. }\end{array}$ & 0 \\
\hline 32 & $\begin{array}{l}\text { Insufficient tasks are } \\
\text { assigned to her, she has } \\
\text { nothing to do. }\end{array}$ & 0 \\
\hline 33 & $\begin{array}{l}\text { They cut off your } \\
\text { initiatives, they don't } \\
\text { allow you to develop } \\
\text { your ideas. }\end{array}$ & $10 \%$ \\
\hline 34 & $\begin{array}{l}\text { They force you to do } \\
\text { absurd or useless tasks. }\end{array}$ & 0 \\
\hline 35 & $\begin{array}{l}\text { They assign you tasks } \\
\text { well below your } \\
\text { competition. }\end{array}$ & 0 \\
\hline 36 & $\begin{array}{l}\text { You are endlessly } \\
\text { overloaded with new and } \\
\text { different tasks. }\end{array}$ & 0 \\
\hline
\end{tabular}

\begin{tabular}{|c|c|c|}
\hline 37 & $\begin{array}{l}\text { They force you to } \\
\text { perform humiliating } \\
\text { tasks. }\end{array}$ & 0 \\
\hline 38 & $\begin{array}{l}\text { You are assigned tasks } \\
\text { that are very difficult or } \\
\text { well above your } \\
\text { preparation, in which you } \\
\text { are very likely to fail }\end{array}$ & 0 \\
\hline 39 & $\begin{array}{l}\text { They force you to do } \\
\text { harmful or dangerous } \\
\text { work. }\end{array}$ & 0 \\
\hline 40 & $\begin{array}{l}\text { They threaten you with } \\
\text { physical violence. }\end{array}$ & 0 \\
\hline 41 & $\begin{array}{l}\text { Receive mild physical } \\
\text { attacks, as a warning. }\end{array}$ & 0 \\
\hline 42 & $\begin{array}{l}\text { They physically attack } \\
\text { you without any } \\
\text { consideration. }\end{array}$ & 0 \\
\hline 43 & $\begin{array}{l}\text { They cause you "on } \\
\text { purpose" expenses to } \\
\text { harm you. }\end{array}$ & $10 \%$ \\
\hline 44 & $\begin{array}{l}\text { They cause damage to } \\
\text { your home or your } \\
\text { workplace. }\end{array}$ & 0 \\
\hline 45 & $\begin{array}{l}\text { You receive direct } \\
\text { physical sexual assault. }\end{array}$ & 0 \\
\hline 46 & $\begin{array}{l}\text { Damage your belongings } \\
\text { or your vehicle. }\end{array}$ & 0 \\
\hline 47 & $\begin{array}{l}\text { They manipulate your } \\
\text { work tools (For example, } \\
\text { they delete files from } \\
\text { your computer). }\end{array}$ & 0 \\
\hline 48 & $\begin{array}{l}\text { Some of your belongings, } \\
\text { documents or work tools } \\
\text { are stolen. }\end{array}$ & $10 \%$ \\
\hline 49 & $\begin{array}{l}\text { Confidential or negative } \\
\text { reports are circulated } \\
\text { about you, without } \\
\text { notifying you or giving } \\
\text { you an opportunity to } \\
\text { defend yourself. }\end{array}$ & 0 \\
\hline 50 & $\begin{array}{l}\text { People who support you } \\
\text { are pressured or } \\
\text { threatened to withdraw } \\
\text { from you. }\end{array}$ & 0 \\
\hline 51 & $\begin{array}{l}\text { They return, open or } \\
\text { intercept your } \\
\text { correspondence. }\end{array}$ & 0 \\
\hline 52 & $\begin{array}{l}\text { They do not pass the calls } \\
\text { or say that he is not there. }\end{array}$ & $10 \%$ \\
\hline 53 & $\begin{array}{l}\text { They lose or forget the } \\
\text { orders that are for you. }\end{array}$ & 0 \\
\hline 54 & $\begin{array}{l}\text { They keep quiet or } \\
\text { minimize their efforts, } \\
\text { achievements or } \\
\text { successes. }\end{array}$ & 0 \\
\hline 55 & $\begin{array}{l}\text { They hide their skills and } \\
\text { abilities. }\end{array}$ & 0 \\
\hline 56 & $\begin{array}{l}\text { They exaggerate their } \\
\text { failures and mistakes. }\end{array}$ & 0 \\
\hline 57 & $\begin{array}{l}\text { They badly value their } \\
\text { permanence and } \\
\text { dedication. }\end{array}$ & 0 \\
\hline 58 & $\begin{array}{l}\text { They control their } \\
\text { schedule excessively and } \\
\text { too strictly. }\end{array}$ & 0 \\
\hline
\end{tabular}

PÉREZ-BRAVO, Julia. Socially responsible practices and workplace harassment, in a municipality as a political administrative organism. Journal-Labor and Demographic economic. 2020 


\begin{tabular}{|r|l|r|}
\hline $\mathbf{5 9}$ & $\begin{array}{l}\text { When you apply for a } \\
\text { permit for a course or } \\
\text { activity to which you are } \\
\text { entitled, it is denied or } \\
\text { put up with obstacles and } \\
\text { difficulties. }\end{array}$ & 0 \\
\hline $\mathbf{6 0}$ & $\begin{array}{l}\text { It is provoked to force } \\
\text { him to react emotionally. }\end{array}$ & 0 \\
\hline
\end{tabular}

Table 2 Frequencies of positive responses to each workplace bullying strategy

Source: Own elaboration with results of application of LIPT 60

As can be seen from the results, the existence of workplace harassment or abuse is practically nil. This is due to the fact that $25 \%$ of the workforce for that unit was surveyed and harassment practices were found in $16.66 \%$, that is, in ten items of the 60 that include the research instrument applied for this effect.

\begin{tabular}{|r|r|l|r|}
\hline No. $\begin{array}{l}\text { Item } \\
\text { No. }\end{array}$ & \multicolumn{2}{|c|}{ Indicator } \\
\hline 1 & 1 & $\begin{array}{l}\text { His superiors do not let him } \\
\text { express himself or say what he } \\
\text { has to say. }\end{array}$ & $10 \%$ \\
\hline 2 & 2 & $\begin{array}{l}\text { They interrupt him when he } \\
\text { speaks. }\end{array}$ & $10 \%$ \\
\hline 3 & 3 & $\begin{array}{l}\text { His classmates make it } \\
\text { difficult for him to express } \\
\text { himself or do not let him } \\
\text { speak. }\end{array}$ & $10 \%$ \\
\hline 4 & 5 & $\begin{array}{l}\text { They unfairly criticize their } \\
\text { work. }\end{array}$ & $30 \%$ \\
\hline 5 & 12 & $\begin{array}{l}\text { People have stopped or are not } \\
\text { talking to you. }\end{array}$ & $10 \%$ \\
\hline 6 & 18 & $\begin{array}{l}\text { They spread false or } \\
\text { unfounded rumors about you. }\end{array}$ & $10 \%$ \\
\hline 7 & 33 & $\begin{array}{l}\text { They cut off your initiatives, } \\
\text { they don't allow you to } \\
\text { develop your ideas. }\end{array}$ & $10 \%$ \\
\hline 8 & 43 & $\begin{array}{l}\text { They cause you "on purpose" } \\
\text { expenses to harm you. }\end{array}$ & $10 \%$ \\
\hline 9 & 48 & $\begin{array}{l}\text { Some of your belongings, } \\
\text { documents or work tools are } \\
\text { stolen. }\end{array}$ & $10 \%$ \\
\hline 10 & 52 & $\begin{array}{l}\text { They do not pass the calls or } \\
\text { say that he is not there. }\end{array}$ & $10 \%$ \\
\hline
\end{tabular}

Table 3 Results of the existence of harassment or labor abuse

Source: Own elaboration with results of application of LIPT 60

With this, it is possible to answer the research question: Do the socially responsible practices carried out in the Directorate of Culture and Tourism exclude harassment or labor abuse?
When noting that of the ten items where they reported the existence of harassment or abuse at work, in nine of them $10 \%$ of the workers surveyed said they had experienced it, and only in one, $30 \%$.

\begin{tabular}{|c|c|c|c|c|}
\hline No. & $\begin{array}{l}\text { Item } \\
\text { No. }\end{array}$ & Indicator & $\begin{array}{l}\text { Subscale } \\
\text { referring to: }\end{array}$ & $\begin{array}{l}\text { LIPT } \\
\text { positive } \\
\text { percentag } \\
\text { e }\end{array}$ \\
\hline 1 & 1 & $\begin{array}{l}\text { His superiors do not } \\
\text { let him express } \\
\text { himself or say what } \\
\text { he has to say }\end{array}$ & Overt intimidation & $10 \%$ \\
\hline 2 & 2 & $\begin{array}{l}\text { You are interrupted } \\
\text { when you speak }\end{array}$ & Overt intimidation & $10 \%$ \\
\hline 3 & 3 & $\begin{array}{l}\text { His classmates put } \\
\text { obstacles in his way } \\
\text { to express himself or } \\
\text { do not let him speak }\end{array}$ & $\begin{array}{l}\text { Incommunication } \\
\text { or communication } \\
\text { blocking }\end{array}$ & 10 \\
\hline 4 & 5 & $\begin{array}{l}\text { They unfairly } \\
\text { criticize their work }\end{array}$ & Labor smear & 30 \\
\hline 5 & 12 & $\begin{array}{l}\text { People have stopped } \\
\text { or are stopping } \\
\text { talking to you }\end{array}$ & $\begin{array}{l}\text { Incommunication } \\
\text { or communication } \\
\text { blocking }\end{array}$ & 10 \\
\hline 6 & 18 & $\begin{array}{l}\text { They circulate false } \\
\text { or unfounded rumors } \\
\text { about you }\end{array}$ & Labor smear & 10 \\
\hline 7 & 33 & $\begin{array}{l}\text { They cut off your } \\
\text { initiatives, they don't } \\
\text { allow you to develop } \\
\text { your ideas }\end{array}$ & $\begin{array}{ll}\text { Slowing } & \text { down } \\
\text { progress } & \end{array}$ & 10 \\
\hline 8 & 43 & $\begin{array}{l}\text { They cause you "on } \\
\text { purpose" expenses to } \\
\text { harm you }\end{array}$ & Covert bullying & 10 \\
\hline 9 & 48 & $\begin{array}{l}\text { Some of your } \\
\text { belongings, } \\
\text { documents or work } \\
\text { tools are stolen }\end{array}$ & Covert bullying & 10 \\
\hline 10 & 52 & $\begin{array}{l}\text { They do not pass the } \\
\text { calls or say that he is } \\
\text { not }\end{array}$ & $\begin{array}{l}\text { Incommunication } \\
\text { or communication } \\
\text { blocking }\end{array}$ & 10 \\
\hline
\end{tabular}

Table 4 Summary results of the existence of harassment or labor abuse

Source: Own elaboration with results of application of LIPT 60

For a clearer perception of these results, the following figures are shown.

Workers surveyed in the study unit

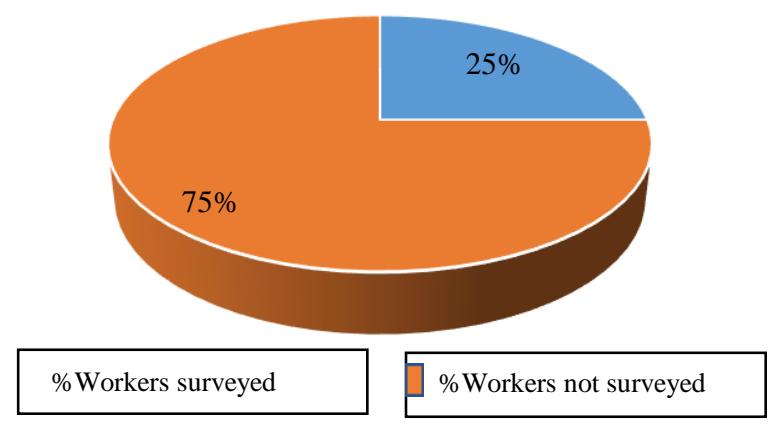

Figure 1 Workers surveyed in the study unit Source: Self made 
Sense of the responses in the survey items

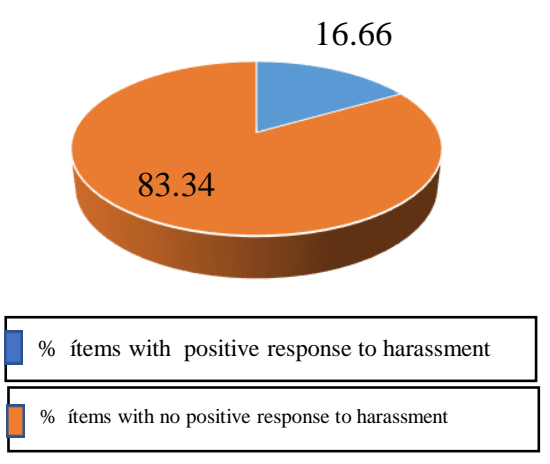

Figure 2 Sense of the responses in the survey items Source: Self made

Results of the existence of harassment
or labor abuse, by gender

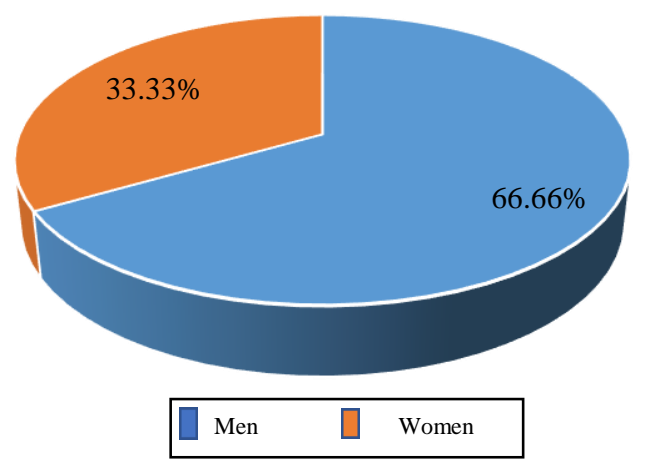

Figura 3 Encuestados que manifiestan existencia de acoso laboral, por género Source: Self made

Results of the existence of harassment or labor abuse

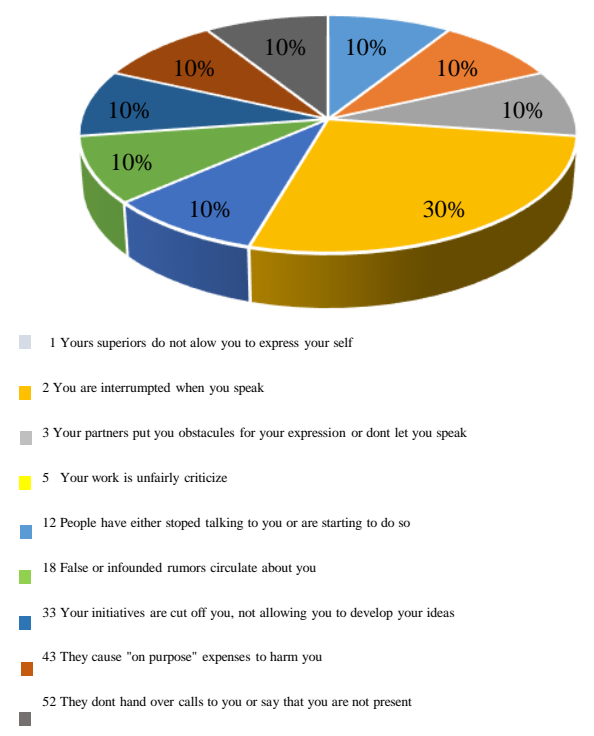

Figura 4 Resultados de la existencia del acoso o maltrato laboral

Source: Self made

\section{Conclusions}

From the analysis of the results obtained, after the application of the research instruments, it is possible to point out as a conclusion that labor abuse exists in a proportion in the dependency in question.

The results indicate that harassment practices were only found in $16.66 \%$, that is, in ten items of the 60 included in the instrument applied, and that, regarding gender, of the cases in which workplace harassment is manifested, the $33.33 \%$ are women and $66.66 \%$ men.

However, the municipal president himself in turn stated that it is in his interest to reduce these practices to a minimum in this and in all the dependencies of the municipality of San Juan del Río as an administrative political body. Therefore, they will provide you with the results and recommendations so that you can take the measures they deem appropriate.

The resulting recommendations are to train staff in matters of social responsibility, as well as in socially responsible practices in labor matters, both those belonging to the management that was studied in this work, as well as those of all the secretariats, directorates and decentralized agencies. This, to prevent labor abuse and promote ethical and responsible treatment in the municipality of San Juan del Rio, Querétaro, as an administrative political body and among all its stakeholders.

\section{References}

Asociación Española de Contabilidad y Administración de Empresas. (2004) Marco Conceptual de la Responsabilidad Social C orporativa. Asociación Española de Contabilidad y Administración de Empresas.

Armas, L. A., Solís, O., y Zárate, G. (2011). Historia y Monumentos del Estado de Querétaro. Gobierno del Estado de Querétaro.

Bourdieu, P. (1997). Razones prácticas sobre la teoría de la acción. Anagrama.

Comisión Europea. (2000). Libro Blanco sobre responsabilidad ambiental. Comisión Europea. http://ec.europa.eu/environment/legal/liability/p df/el_full_es.pdf 
De la Llata, M. (1976). México y su costosa independencia, así es Querétaro. Costa-Amic.

Durán, A., Durán A. y Giraldo, E. (2004) El reto de la acreditación progresiva. Aplicación a herramientas de Gestión de la Responsabilidad Social Corporativa. En VIII Congreso de Ingeniería de Organización (pp.355-365). Asociación para el Desarrollo de la Ingeniería de Organización.

http://www.researchgate.net/publication/45448

444_El_reto_de_la_acreditacin_progresiva._Ap licacin_a_herramientas_de_Gestion_de_la_Res ponsabilidad_Social_Corporativa

Echávarri, R. (2006). San Juan del Rio, Geografia e Historia. Gobierno del Estado de Querétaro.

El Rotativo. San Juan del Río primero en recibir Distintivo "M" de SECTUR. https://rotativo.com.mx/noticias/locales/sanjuan-del-rio/547607-san-juan-del-rio-primerorecibir-distintivo-m-sectur/

Entrena, R. (1986). Curso de derecho administrativo (Vol. 1). Editorial Tecnos.

Fernández Ruiz, Dr. J. y Gámiz Parral, Dr. M.N. (1990) CAP. II. DERECHO CONSTITUCIONAL Y ADMINISTRATIVO DE LAS ENTIDADES FEDERATIVAS. Universidad Nacional Autónoma de México. Disponible en: http://biblio.juridicas.unam.mx/libros/3/1165/4. pdf, Recuperado en agosto, 2015.

Fernández, F. (2009). Responsabilidad social corporativa. Editorial Club Universitario

Gómez, M. G. (2011). Autonomía del órgano de control interno en el municipio de San Juan del Río, Qro, por medio de la creación de una entidad paramunicipal [Tesis de Licenciatura]. Universidad Autónoma de Querétaro.

González de Rivera, M. (2002). El maltrato psicológico. Calpe.

González de Rivera, J.L. (2002). El maltrato psicológico, COMO defenderse del Mobbing y otras formas de Acoso. Editorial Espasa Práctico.
González, J. L. y Rodríguez-Abuin, M. (2003). Cuestionario de estrategias de acoso psicológico: El LIPT -60. Psiquiatría.com. http://www.psiquiatria.com/psiquiatria_legal/cu estionario-de-estrategias-de-acoso-psicologicoel-lipt-60/\#

González, J. L. y Rodríguez-Abuin, M. J. (2005). Cuestionario de estrategias de acoso en el trabajo. El LIPT-60. Editorial EOS.

Gutiérrez, E. (2014). El acoso psicológico en el trabajo y su impacto en el clima laboral, en una organización educativa y otra de salud [Tesis doctoral, Universidad Autónoma de Querétaro]. www.uaq.mx

H. Ayuntamiento de San Juan del Río. (s.f.). Manual General de la Organización del Municipio de San Juan del Río, Querétaro. H. Ayuntamiento de San Juan del Río http://www.sanjuandelrio.gob.mx/uig/docs/f4/ Manuales/Manual\%20General\%20de\%20organ izaci\%C3\%B2n\%20-

\%20Administraci\%C3\%B3n\%202012-2015.pdf

Instituto Nacional de Estadística y Geografía. (2009). Censos Económicos, Querétaro. Instituto Nacional de Estadística y Geografía. http://www.inegi.org.mx/est/contenidos/espanol /proyectos/censos/ce2009/pdf/M_Queretaro.pdf

Instituto Nacional de Estadística y Geografía. (2009). México en cifras. Información nacional por entidad federativa y municipios. Instituto Nacional de Estadística y Geografía.

http://www3.inegi.org.mx/sistemas/mexicocifra s/datos-geograficos/22/22016.pdf

Instituto Nacional de Estadística y Geografía. (2011). Panorama Sociodemográfico de Querétaro. Censo de Población y Vivienda 2010. Instituto Nacional de Estadística y Geografía.

Instituto Nacional para el Federalismo y el Desarrollo Municipal. (2010). Enciclopedia de los Municipios y Delegaciones de México, Querétaro de Arteaga. http://www.inafed.gob.mx/work/enciclopedia/E MM22queretaro/municipios/22016a.html

Leymann, H. (1990). ¿Qué es el Mobbing?. http://contenidos.universia.es/especiales/mobbi ng/concepto. 
Leymann, H. (1990). MOBBING y terror psicológico en los lugares de trabajo. Revista Violence and Victims, 5(2).

Lizcano, J. L. y Nieto, P. (2005). ¿Responsabilidad social corporativa o solo corporativa? Asociación Española de Contabilidad y Administración de Empresas.

López, G. (2010). La realidad española de la RSC a través de los informes de sostenibilidad de las empresas en el bienio 2006-2007 [Tesis doctoral]. Universidad Complutense de Madrid.

Ministerio de administración y gestión pública del municipio de Córdoba en Argentina, a través de

http://www.cba.gov.ar/micrositio/responsabilid ad-social2012/accionarpolitica.html

Observatorio de la RSC (2005). Informe del foro de expertos en responsabilidad social de las empresas. Ministerio de Empleo y Seguridad Social.

http://www.empleo.gob.es/es/sec_trabajo/auton omos/economia-

soc/RespoSocEmpresas/foro_expertos/contenid os/INFORME_FOROEXPERTOS_RSE.pdf

Organización Internacional de Estandarización. (2010). ISO 26000 Responsabilidad Social. Organización Internacional de Estandarización http://www.iso.org/iso/discovering_iso_26000es.pdf

Oxfam International, a través de https://www.oxfam.org/es

Peraza, A. J. (2014). Propuesta de un modelo gerencial estratégico socialmente responsable basado en el gobierno electrónico para la gestión de los gobiernos locales en el Estado de Aragua [Tesis Doctoral, Universidad de Canaboro].

http://www.cladea.org/index.php?option=com phocadownload $\&$ view $=$ category $\&$ download $=1$ 26:propuesta-de-un-modelo-gerencialestrategico-socialmente-responsable-basado-enel-gobierno-electronico-para-la-gestion-de-losgobiernos-locales-en-el-estadoaragua\&id=8:viii-coloquio-predoctoral\&Itemid $=356$
Rebolledo, O. (2005). El marco jurídico del municipio en un contexto federalizado. En S. Valencia (Coord.), El municipio en México y en el mundo: Primer Congreso Internacional de Derecho Municipal (pp. 379-387). Universidad Nacional Autónoma de México-Instituto de Investigaciones Jurídicas. http://biblio.juridicas.unam.mx/libros/libro.htm $? 1=1736$

Robles, R. (2004). El Municipio. Editorial Porrúa.

Trujillo, Lámbarry y Valderrabano (2014). Quantification of mobbing in the mexican financial sector from a gender perspective. Convergencia. Revista de Ciencias Sociales, 22(67), 211-233. www.redalyc.org

Vázquez, P. (2003). El Municipio Mexicano: Nuevo Nivel de Gobierno [Tesis de Maestría, Universidad Autónoma de Nuevo León]. http://cdigital.dgb.uanl.mx/te/1020149320/1020 149320.PDF

Verona, M. C., Déniz, J.J. y Santana, R. (2014). Consecuencias y responsabilidades de la empresa ante el mobbing. Ciencias y Sociedad, 39(3),

413-440. http://www.redalyc.org/articulo.oa?id=8703189 7002

Weber, M. (s.f.). Qué es la burocracia. http://www.ucema.edu.ar/u/ame/Weber_burocra cia.pdf. 